\title{
Meiotic behavior during microsporogenesis of Alchornea triplinervia (Sprengel) Müller Argoviensis
}

\author{
Comportamento meiótico durante a microsporogênese de Alchornea triplinervia (Sprengel) Müller \\ Argoviensis
}

\author{
Sara Mataroli de GodoyI Andréia Rodrigues Alonso Pereira' ${ }^{\mathrm{I}}$ Mariza Barion Romagnolo ${ }^{\mathrm{II}}$ \\ Claudicéia Risso-Pascotto ${ }^{\mathrm{I}^{*}}$
}

\begin{abstract}
The Alchornea triplinervia specie belongs to the Euphorbiaceae family, one of the main families of the Brazilian flora. In order to contribute to a better understanding of the specie, a counting of chromosome number and the microsporogenesis analysis of A. triplinervia were done. The inflorescences were collected in the municipalities of Paranavai and Diamante do Norte, State of Paraná, Brazil, and the slides were prepared by squashing technique and staining with $1 \%$ acetic carmine. The analysis were performed using an optical microscope and showed a chromosome number for the specie equal to $2 n=8 x=72$. Irregularities in the chromosome segregation process were the main meiotic abnormalities, presenting typical polyploid behavior. Other irregularities were observed; however, at low frequency without compromising the pollen grain formation of the analyzed plants.
\end{abstract}

Key words: Euphorbiaceae, chromosome number, 2n gametes, meiosis, polyploid.

\section{RESUMO}

A espécie Alchornea triplinervia pertence à família Euphorbiaceae, uma das principais famílias da flora brasileira. Visando a contribuir para um melhor entendimento da espécie, foi realizada a contagem do número de cromossomos e a análise da microsporogênese de A. triplinervia. As Inflorescências foram coletadas nos Municípios de Paranavaí e Diamante do Norte, no Estado do Paraná, Brasil, sendo as lâminas preparadas pela técnica de esmagamento e coradas com carmim acético $1 \%$. As análises foram realizadas ao microscópio óptico, revelando um número cromossômico para a espécie igual a $2 n=8 x=72$. Irregularidades no processo de segregação dos cromossomos foram as principais anormalidades meióticas, mostrando comportamento típico de poliploides. Outras irregularidades foram observadas, porém, em baixa frequência, não comprometendo a formação dos grãos de pólen das plantas analisadas.

Palavras-chave: Euphorbiaceae, número cromossômico, gametas $2 n$, meiose, poliploide.

\section{INTRODUCTION}

The Euphorbiaceae botanical family comprises around 290 genus and 7,500 species with great variations, ranging from woody to herbaceous plants. In Brazil there are approximately 70 genus and 1,000 species, native and exotic ones, representing one of the main families of the Brazilian flora and one of the most complex ones taxonomically (BARROSO, 1991; SOUZA \& LORENZI, 2005). Several species belonging to this family have economic interest and among them are: the rubber tree (Hevea brasiliensis), cassava (Manihot esculenta) and beaver beans (Ricinus communis). There are also other species used in ornamentation (LORENZI, 2002; SOUZA \& LORENZI, 2005).

Alchornea triplinervia is a specie of great environmental importance because it is indicated for reforestation of degraded areas. The aril that involves its seeds is used as food by birds and its wood can be used in the making of boxes, doors and crutches (LORENZI, 2002).

Cytologically, the Alchornea genus has been little studied, and the studies are limited to the

'Biotecnologia Aplicada à Agricultura, Universidade Paranaense (UNIPAR), Av. Huberto Brüning, 360, 87706-560, Paranavaí, PR, Brasil. E-mail: claudiceiarp@unipar.br. *Autor para correspondência.

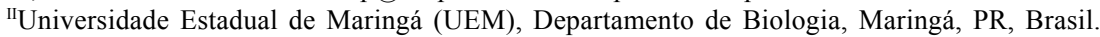


counting of chromosome number. In the Alchornea genus has been cited $\mathrm{x}=8,9,10$ or 11 as basic chromosome numbers for most species (HANS, 1973). Cytogenetic data obtained from the observation of number and morphology of chromosomes as well as the behavior and meiotic division process, have been utilized to understand chromosome evolution, phylogeny and taxonomic relations (GUERRA \& NOGUEIRA, 1990). In order to contribute to a better understanding of the species, this study reports the chromosome number and the abnormalities of the meiotic behavior through the analysis of the microsporogenesis A. triplinervia.

\section{MATERIALS AND METHODS}

Botanical material and inflorescences at the initial development stage of $\boldsymbol{A}$. triplinervia were collected in the Municipal Park of the city of Paranavaí, Paraná - Brazil (23 $05^{\prime}$ S and $\left.52^{\circ} 27^{\prime} \mathrm{W}\right)$, and at the Ecological Station of Caiuá, located in the municipality of Diamante do Norte, Paraná State - Brazil (22 $2^{\circ} 41^{\prime} \mathrm{S}$ and $52^{\circ} 55^{\prime} \mathrm{W}$ ).

Reproductive and vegetative parts of four plants were collected and herborized according to the usual techniques (FIDALGO \& BONONI, 1989), and are stored at the Herbarium of Maringá State University (HUEM). The inflorescences at the initial development stage were collected for meiotic studies and, immediately after the collection, were fixed in a mixture of ethanol and acetic acid (3:1 v/v) for 24 hours at room temperature. After the fixation period, the material was washed in alcohol at $70 \%$ and stored in alcohol at $70 \%$ under refrigeration.

In the time of the study, the inflorescences were dissected with the help of a stereomicroscope for the withdrawal of anthers that were used to prepare semi-permanent slides by squashing technique, and staining with $1 \%$ acetic carmine. Microsporocytes were analyzed under binocular optical microscope Motic, B1 series, model 220A. Cells from the metaphase I to tetrad phases, besides microspores and pollen grains were observed. Photomicrographies were obtained with a digital camera, DCE- 2 Image Driving Soft Ware, and only contrast and brightness were altered.

Plants collected at the Municipal Park of Paranavaí (MPP) will be named MPP I and MPP II and the plants collected at the Environmental Station of Caiuá (ESC) will be named ESC I and ESC II.

\section{RESULTS AND DISCUSSION}

Chromosome counting during microsporogenesis (Figure 1A) showed that all analyzed plants presented $2 \mathrm{n}=8 \mathrm{x}=72$ chromosomes. In diakinesis, the chromosomes were predominantly associated as bivalents, but univalents and tetravalent were also observed in a lower frequency (Figure 1A).

Considering $\mathrm{x}=9$ as the basic number of chromosomes for the species of the genus, A. triplinervia is an octaploid $(2 n=8 x=72)$. This statement is based on the described number of chromosome for the species of Alchornea genus, where $\mathrm{n}=9$ are considered the haploid chromosome number of Alchornea tiliifolia Müll. Arg. (HANS, 1973) and Alchornea hirtella Benth. (SCHMELZER \& GURIB-FAKIM, 2008), 2n=18 chromosomes as the diploid number of the Alchornea floribunda (HANS, 1973; SCHMELZER \& GURIBFAKIM, 2008) and Alchornea laxiflora (Benth.) Pax \& Hoffm species, and $2 \mathrm{n}=36$ chromosomes for Alchornea cordifolia (Schumach. \& Thonn.) Müll. arg. (SCHMELZER\& GURIB-FAKIM, 2008).

No records were found in the literature on the meiotic behavior of the genus to which $\boldsymbol{A}$. triplinervia specie belongs, and the few cytogenetic studies that were found are restrict to the counting of chromosome number for some species. In this study, the meiotic behavior of four A. triplinervia plants during microsporogenesis was analyzed. The number of analyzed cells and the percentage of irregularities in each meiosis phase can be observed on table 1 .

In the chromosomes segregation process, the observed irregularities were: precocious chromosomes migration in metaphases (Figure 1C and I), laggard chromosomes in anaphases (Figure 1D and $\mathrm{J})$, micronuclei in telophases (Figure 1F, K and L), and tetrads with microcytes (Figure 2D). These constituted the main abnormalities observed in the four studied $\boldsymbol{A}$. triplinervia plants and according to SINGH (1993) this is a typical meiotic behavior of polyploids.

The greater frequency of precocious migration in metaphases I (Figure 1C) was observed in MPP I plant (13.04\%) and the lowest frequency in ESC II plant $(4.76 \%)$. The chromosomes in precocious migration in metaphases I may have originated from univalents in diakinesis or have been a result of precocious terminalization of chiasma and the late terminalization of these chiasmas makes the laggard chromosomes in anaphase I (SOUZA-KANESHIMA et al., 2010).

Laggard chromosomes (Figure 1D and J) were visualized in MPP I and MPP II plants, affecting $16.83 \%$ of meiocytes in anaphase I and $35.90 \%$ in anaphase II, respectively. The presence of irregular chromosome behavior in metaphases and anaphases in the Euphorbiaceae family was observed by NASSAR (2000) in a cytogenetic and evolutive study of Manihot esculenta Crantz, where there was precocious chromosome migration in metaphase I and II, and laggard chromosomes in anaphase I and II. RISSO-PASCOTTO et al. (2005), in an analysis of 


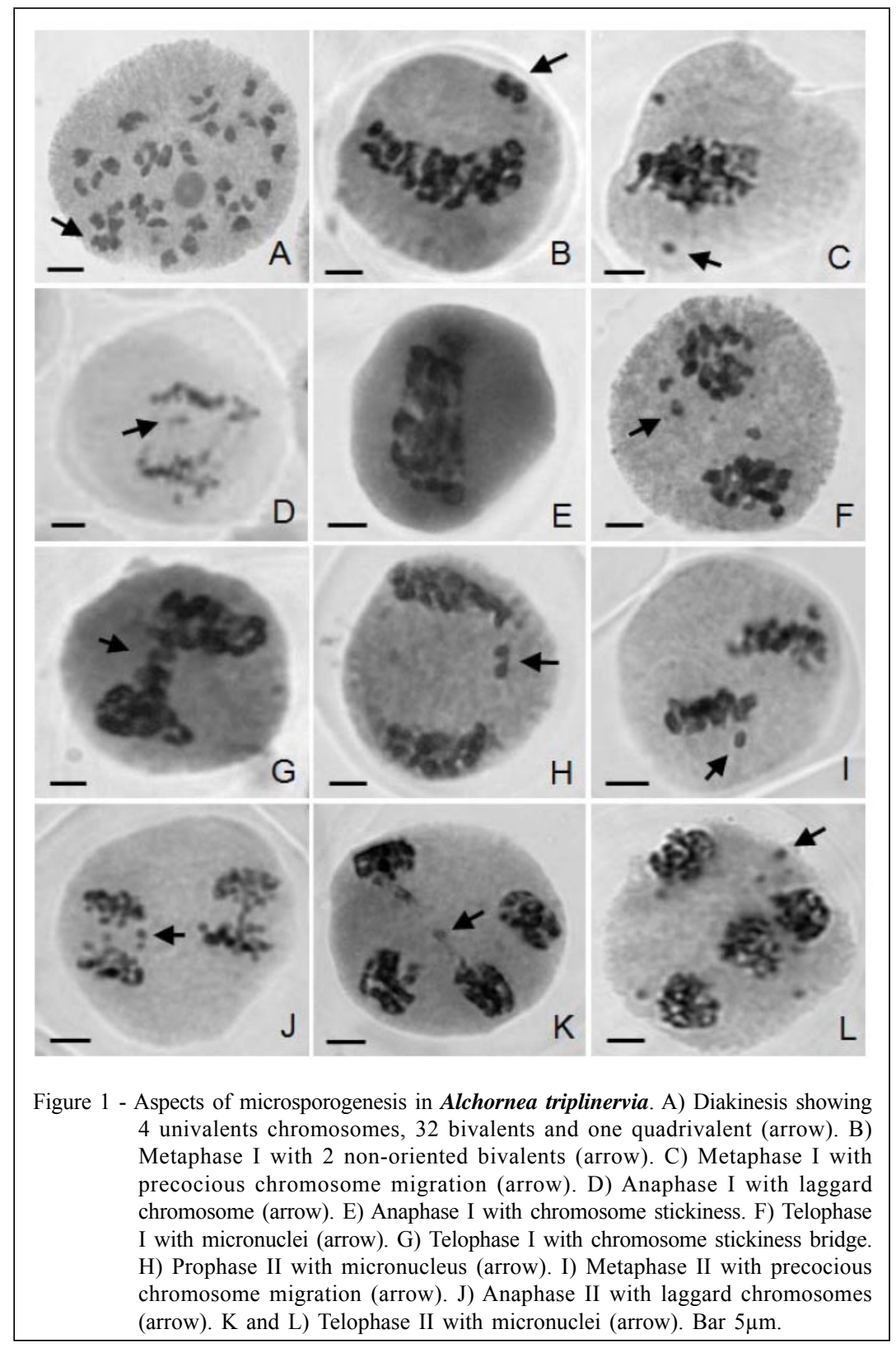

microsporogenesis in Brachiaria ruziziensis, it was reported the occurrence of precocious chromosome migration and laggard chromosomes.

Non-oriented bivalents (Figure $1 \mathrm{~B}$ ) as well as chromosomes in precocious migration and laggards may lead to the formation of micronuclei in telophase I if they are not reintegrated to the telophasic nucleus (KONGPRAKHON et al., 2005). RISSO-PASCOTTO et al. (2003) suggest that non-oriented chromosomes result from a linking failure of spindle fibers to the kinetochore, making them disperse in the cytoplasm.

The frequency of chromosome stickiness (Figure 1E) ranged from absent in ESC II plant up to
$23.88 \%$ in anaphases of MPP II plant. The stickiness is characterized as a chromosome grouping during some phases of the cellular cycle that according to PAGLIARINI (2000), may be caused by environmental causes as well as genetic control. GAULDEN (1987) suggest that chromosome stickiness its caused by a failure in the functioning of one of the two non-histone proteins involved in the process of chromosome separation and segregation. According to author, this failure could be caused by mutations in genes that codify these proteins, being the chromosome stickiness hereditary, or by mutagenic agents that act on these proteins which would lead to induced stickiness. In 
Table 1 - Frequencies of meiotic abnormalities and of microspores and pollen grains of four A. triplinervia plants.

\begin{tabular}{|c|c|c|c|c|}
\hline \multirow{2}{*}{ Phase Abnormalities } & \multicolumn{4}{|c|}{ - } \\
\hline & MPP I & MPP II & ESC I & ESC II \\
\hline Metaphase I & $230(82.61 \%)$ & $71(78.87 \%)$ & $66(83.33 \%)$ & $63(93.65 \%)$ \\
\hline Precocious chromosome migration & $31(13.04 \%)$ & $8(11.27 \%)$ & $6(9.09 \%)$ & $3(4.76 \%)$ \\
\hline Non-oriented bivalent & $10(4.35 \%)$ & $7(9.86 \%)$ & $5(7.58 \%)$ & $1(1.59 \%)$ \\
\hline Anaphase I & $208(82.21 \%)$ & $67(76.12 \%)$ & $61(98.36 \%)$ & $58(100 \%)$ \\
\hline Laggard chromosome & $35(16.83 \%)$ & - & - & - \\
\hline Chromosome stickiness & $2(0.96 \%)$ & $16(23.88 \%)$ & $1(1.64 \%)$ & - \\
\hline Telophase I & $233(75.97 \%)$ & $163(90.80 \%)$ & $60(91.67 \%)$ & $54(94.44 \%)$ \\
\hline Micronucleus & $48(20.60 \%)$ & $15(9.20 \%)$ & $5(8.33 \%)$ & $3(5.56 \%)$ \\
\hline Chromosome stickiness bridge & $8(3.43 \%)$ & - & - & - \\
\hline Prophase II & $222(99.10 \%)$ & $135(78.52 \%)$ & $60(98.33 \%)$ & $65(100 \%)$ \\
\hline Micronucleus & $2(0.90 \%)$ & $29(21.48 \%)$ & $1(1.67 \%)$ & - \\
\hline Metaphase II & $244(79.51 \%)$ & $94(81.92 \%)$ & $57(87.72 \%)$ & $78(75.64 \%)$ \\
\hline Precocious chromosome migration & $32(13.11 \%)$ & $10(10.64 \%)$ & $6(10.53 \%)$ & $8(10.26 \%)$ \\
\hline Non-oriented univalent & $12(4.92 \%)$ & $4(4.25 \%)$ & $1(1.75 \%)$ & $7(8.97 \%)$ \\
\hline Tripolar spindle & $6(2.46 \%)$ & $3(3.19 \%)$ & - & $4(5.13 \%)$ \\
\hline Anaphase II & $242(80.99 \%)$ & $78(61.54 \%)$ & $53(100 \%)$ & $77(96.10 \%)$ \\
\hline Laggard chromosome & $41(16.94 \%)$ & $28(35.90 \%)$ & - & - \\
\hline Tripolar spindle & $5(2.07 \%)$ & $2(2.56 \%)$ & - & $3(3.90 \%)$ \\
\hline Telophase II & $241(91.29 \%)$ & $246(73.58 \%)$ & $61(98.36 \%)$ & $82(92.68 \%)$ \\
\hline Micronucleus & $13(5.39 \%)$ & $50(20.32 \%)$ & $1(1.64 \%)$ & $2(2.44 \%)$ \\
\hline Tripolar spindle & $5(2.08 \%)$ & $8(3.25 \%)$ & - & $3(3.66 \%)$ \\
\hline Nuclear restitution & $3(1.24 \%)$ & $7(2.85 \%)$ & - & $1(1.22 \%)$ \\
\hline Tetrad & $223(87.90 \%)$ & $124(83.87 \%)$ & $78(96.16 \%)$ & $69(98.55 \%)$ \\
\hline With microcytes & $3(1.34 \%)$ & $5(4.03 \%)$ & - & $1(1.45 \%)$ \\
\hline Triad & $21(9.42 \%)$ & $1(0.81 \%)$ & $2(2.56 \%)$ & - \\
\hline Dyad & $3(1.34 \%)$ & $3(2.42 \%)$ & $1(1.28 \%)$ & - \\
\hline Dyad with microcytes & - & $11(8.87 \%)$ & - & - \\
\hline Microspores & $319(94.04 \%)$ & $397(96.98 \%)$ & $57(96.49 \%)$ & $109(91.74 \%)$ \\
\hline Unbalanced & $5(1.57 \%)$ & $10(2.52 \%)$ & $2(3.51 \%)$ & $9(8.26 \%)$ \\
\hline 2n microspore & $14(4.39 \%)$ & $2(0.50 \%)$ & - & - \\
\hline Pollen grain & $316(93.04 \%)$ & $577(90.99 \%)$ & $123(97.56 \%)$ & $664(91.57 \%)$ \\
\hline Unbalanced & $5(1.58 \%)$ & $48(8.32 \%)$ & $2(1.63 \%)$ & $50(7.53 \%)$ \\
\hline 2n Pollen grain & $17(5.38 \%)$ & $4(0.69 \%)$ & $1(0.81 \%)$ & $6(0.90 \%)$ \\
\hline
\end{tabular}

*MPP: Collected plant in Municipal Park of Paranavaí; ESC: Collected plant in Ecological Station of Caiuá.

studies on corn, CAETANO-PEREIRA et al. (1995) report chromosome stickiness caused by aluminum saturation in the soil, showing an environmental factor as the cause of that abnormality.

Chromosome grouping during metaphase I and anaphase I led to the formation of chromosome stickiness bridges in telophase I (Figure 1G), observed only in MPP I. According to MENDES-BONATO et al. (2001), the occurrence of non-terminalization of chiasma or the presence of chromosome stickiness is a factor that competes for the formation of chromosome bridges which may persist until telophase or break down, forming micronuclei.
The presence of micronuclei in telophases I (Figure 1F) and II (Figure 1K and L) was observed in the four plants of this study, ranging from $1.64 \%$ to $20.60 \%$. The formation of micronuclei was observed in Avena sativa by BAPTISTA-GIACOMELLI et al. (2000), in which the authors report the elimination of micronuclei in the tetrad phase, giving rise microspores with and amount of unbalanced genetic material. In $A$. triplinervia, despite the great number of micronuclei, few tetrads presented microcytes (Figure 2D). The most probable cause of micronucleus formation is the irregular segregation of chromosomes during the meiotic process (PAGLIARINI et al., 1993; MENDESBONATO et al., 2002).

Ciência Rural, v.42, n.6, jun, 2012. 


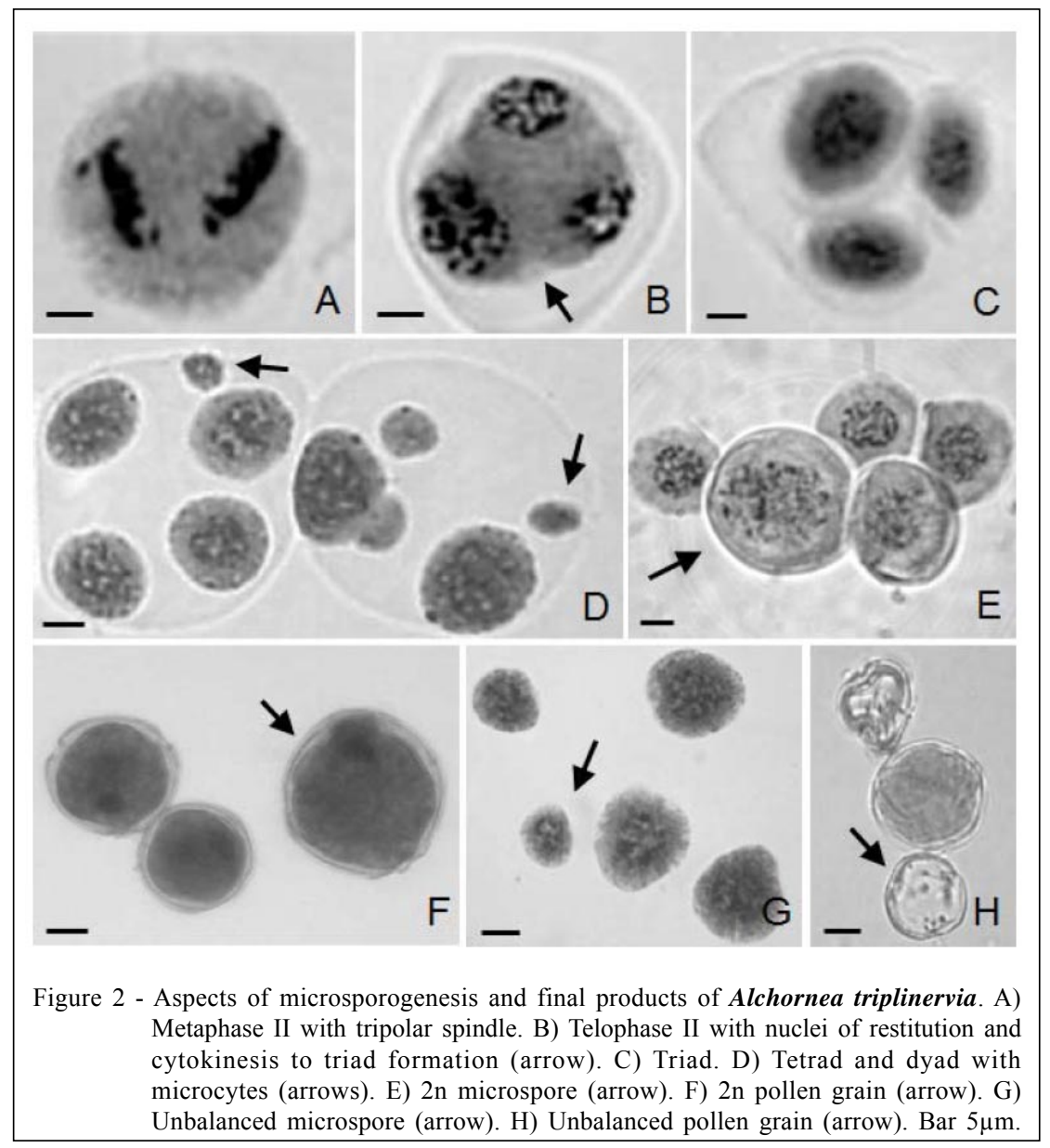

Another observed abnormality, during the analysis of microsporogenesis of $\boldsymbol{A}$. triplinervia, was the occurrence of irregular spindles. Three of the analyzed plants, MPP I, MPP II and ESC II, presented this irregularity. The presence of tripolar spindles during metaphase II (Figure 2A) and anaphase II ended with the fusion of nuclei in telophase II (Figure 2B). According to ENDOW (1999) tripolar spindle can also be called convergent spindle or $\mathrm{V}$ spindle and, this irregularity can result in the fusion of two close nuclei, originating, at the end of the meiosis, triads instead of tetrads. The irregular organization of spindles is due to a mutation in the gene that controls the meiotic division (SHAMINA et al., 2000).

PAGLIARINI et al. (1992), in a cytological observation of Ochna sp., report the phenomenon of the convergence of two spindles into a single cellular pole, thus resulting in the occurrence of telophase II with only three nuclei, one of them being $2 \mathrm{n}$. In $A$. triplinervia, the formation of triads (Figure 2C) and dyads (Figure 2D) was observed; thus occurring the restitution of nuclei in two cell poles. These irregularities culminated in the formation of microspores $2 \mathrm{n}$ (Figure
2E), as well as the micronuclei produced microspores with reduced amount of genetic material, being called unbalanced microspores.

The presence of irregular spindles ending in the formation of restitution nuclei $(2 n)$ has been reported in different species of Brassica napus and Brassica campestris (SOUZA et al. 1999), Medicago sativa (MARIANI et al., 2000), Achillea species (SHEIDAI et al., 2009) and Passiflora genus plants (SOUZA et al., 2003; KIIHL et al., 2010).

Abnormal microspores give rise pollen grains with different sizes and amount of genetic material, pollen grains $2 \mathrm{n}$ and unbalanced (Figure $2 \mathrm{G}$ ). All analyzed $\boldsymbol{A}$. triplinervia plants presented pollen grains 2n (Figure 2F) and unbalanced (Figure 2H), ranging from $0.69 \%$ to $5.38 \%$ and $1.58 \%$ to $8.32 \%$, respectively.

\section{CONCLUSION}

According to the analysis done on $\boldsymbol{A}$. triplinervia species, it may be concluded that the 
species has chromosome number $2 \mathrm{n}=8 \mathrm{x}=72$, a polyploid, and despite of the abnormalities occurred in the meiotic process, these did not interfere in the reproduction and development of plants because the frequency of unviable pollen grains is low.

\section{REFERENCES}

BAPTISTA-GIACOMELLI, F.R. et al. Elimination of micronuclei from microspores in a Brazilian oat (Avena sativa L.) variety. Genetics and Molecular Biology , v.3, p.681684, 2000.

BARROSO, G.M. Sistemática de Angiospermas do Brasil. Viçosa, MG: Universidade Federal de Viçosa, 1991. 377p.

CAETANO-PEREIRA, C.M. et al. Influence of aluminum in causing chromosome stickiness in maize microsporocytes. Maydica, v.40, p.325-330, 1995.

ENDOW, S.A. Microtubule motors in spindle and chromosome motility. European Journal of Biochemistry, v.262, p.1218,1999 .

FIDALGO, O.; BONONI, V.L.R. Técnicas de coleta, preservação e herborização de material botânico. São Paulo, SP: Instituto de Botânica/Secretaria do Meio Ambiente, 1989. 62p.

GAULDEN, M.E. Hypothesis: some mutagens directly alter specific chromosomal proteins (DNA topoisomerase II and peripheral proteins) to produce chromosome stickiness, which causes chromosome aberrations. Mutagenesis, v.2, p.357$365,1987$.

GUERRA, M.; NOGUEIRA, M.T.M. The cytotaxonomy of Emilia spp. (Asteraceae: Senecione) occuring in Brazil. Plant Systematics and Evolution, v.170, p.229-236, 1990.

HANS, A.S. Chromosome conspectus of the Euphorbiaceae. Taxon, v.22, p. 591-636, 1973.

KIIHL, P.R.P. et al. Abnormal behavior of spindle during microsporogenesis of Passiflora (Passifloraceae). Arquivos de Ciências da Saúde da Unipar, v.14, p. 237-243, 2010.

KONGPRAKHON, P. et al. Meiosis of vetiver germplasm in Thailand. Assumption Journal University Technology, v.1, p.9-14, 2005. Available from: <http://www.vetiver.org/ THA_meiosis.pdf>. Accessed: Jan. 22, 2011.

LORENZI, H. Árvores brasileiras: manual de identificação e cultivo de plantas arbóreas do Brasil. 4.ed. Nova Odessa, SP Instituto Plantarum, 2002. 368p.

MARIANI, A. et al. Meiotic mutants of Medicago sativa show altered levels of $\alpha$ - and $\beta$-tubulin. Genome, v.43, p.166-171, 2000. Available from: <http://www.nrcresearchpress.com/doi/ pdf/10.1139/g99-105>. Accessed: Jan. 22, 2011.

MENDES-BONATO, A.B. et al. A severe case of chromosome stickness in pollen mother cells of Brachiaria brizantha (Hochst.) Stapf (Gramineae). Cytologia, v.66, p.287-291, 2001.

MENDES-BONATO, A.B. et al. Chromosome numbers and microsporogenesis in Brachiaria brizantha (Gramineae). Euphytica, v.125, p.419-425, 2002.
NASSAR, N.M.A. Cytogenetics and evolution of cassava (Manihot esculenta Crantz). Genetics and Molecular Biology, v.23, p.1003-1014, 2000. Available from: <http://www.scielo.br/ $\mathrm{pdf} / \mathrm{gmb} / \mathrm{v} 23 n 4 / 6263 . \mathrm{pdf}>$. Accessed: Jan. 22, 2011.

PAGLIARINI, M.S. et al. Some considerations on the cytology in Ochna sp. (Ochnaceae). Cytologia, v.57, p.237-240, 1992.

PAGLIARINI, M.S. et al. Chromosomal behavior and sees production in Chloropytum comosum (Liliaceae). Cytologia, v.58, p.433-437, 1993.

PAGLIARINI, M.S. Meiotic behavior of economically important plant species: the relationship between fertility and male sterility. Genetics and Molecular Biology, v.23, p.9971002, 2000. Available from: <http://www.scielo.br/pdf/gmb/ v23n4/6262.pdf $>$. Accessed: Jan. 27, 2011.

RISSO-PASCOTTO, C. et al. A mutation in the spindle checkpoint arresting meiosis II in Brachiaria ruziziensis. Genome, v.46, p.724-728, 2003. Available from: <http:// www.nrcresearchpress.com/doi/pdf/10.1139/g03-037>. Accessed: Jan. 27, 2011.

RISSO-PASCOTTO, C. et al. Mutiple spindles and cellularization during microsporogenesis in an artificially induced tetraploid accession of Brachiaria ruziziensis (Gramineae). Plant Cell Reports, v.23, p.522-527, 2005.

SCHMELZER, G.H.; GURIB-FAKIM, A. Plant resources of tropical Africa 11 (1). Medicinal plants I. Wageningen, Netherlands/CTA: PROTA Foundation, 2008. 791p.

SHAMINA, N. et al. Radial spindle and the phenotype of the maize meiotic mutant, $D V$. Cell Biology International, v.24, p.729-736, 2000.

SHEIDAI, M. et al. New chromosome number and unreduced pollen formation in Achillea species (Asteraceae). Acta Biologica Szegediensis, v.53, p.39-43, 2009. Available from: <http://www.sci.u-szeged.hu/ABS/2009/Acta\%20HP/ 5339.pdf>. Accessed: Jan. 27, 2011.

SINGH, R.J. Plant Cytogenetics. Boca Raton, FL: CRC, 1993. 391p.

SOUZA, A.M. et al. Abnormal spindles in second meiosis in canola (Brassica napus and Brassica campestris). Brazilian Archives of Biology and Tecnology, v.42, p.47-52, 1999. Available from: <http://www.scielo.br/pdf/babt/v42n1/ v42n1a07.pdf $>$. Accessed: Jan. 22, 2011.

SOUZA, V.C.; LORENZI, H. Botânica sistemática: guia ilustrado para identificação das famílias de Angiospermas da flora brasileira. Nova Odessa, SP: Instituto Plantarum, 2005. $640 \mathrm{p}$.

SOUZA, M.M. et al. Meiotic irregularities and pollen viability in Passiflora edmundoi Sacco (Passifloraceae). Caryologia, v.56, p.161-169, 2003. Available from: <http://www1.unifi.it/ caryologia/past_volumes/56_2/Caryologia_Vol_56_161169.pdf $>$. Accessed: Jan. 12, 2011.

SOUZA-KANESHIMA, A.M. et al. Meiotic behaviour in the first interspecific hybrids between Brachiaria brizantha and Brachiaria decumbes. Plant Breeding, v.129, p.186-191, 2010. 